\title{
Test bench measurement of friction loss in combustion engine
}

The results of modeling and bench testing friction losses in the main engine kinematic nodes for different lubricating oil temperature values was presented in the article. The study was performed to evaluate the effect of lubricating oil temperature on the engine friction losses. In addition to friction losses in the crankshaft bearings and the piston rings in a cylinder-piston group the friction loss due to charge exchange in the cylinder, drive of timing system and the oil pump were measured. The obtained results show the course of the friction loss in the combustion engine. The research shows that the thermal state of the engine lubricating oil has effect on the amount of friction losses. Formulated conclusions allow to assess the impact of the oil temperature on the friction losses in the main friction nodes in combustion engine.

Key words: combustion engine, piston, oil, lubrication, friction loss

\section{Introduction}

Every year the number of vehicles on the roads and highways increases. Distances traveled by cars are often small, because the drivers move only in the urban area. In heavy traffic, a large number of lights on streets often creates congestion. In such traffic conditions, the engines of motor vehicles operate under idle and low loads, generating mechanical losses a relatively large value. It mainly translates into an increased amount of fuel consumption and exhaust emissions. Furthermore, referring to the small distances that the vehicle passes, it is not possible for an internal combustion engine to achieve optimum operating temperature. It has a great influence on the friction loss generated in the drive unit $[1,2]$.

Reducing friction losses has the effect of decreasing fuel consumption and increasing mechanical efficiency $[1,7]$. One of the friction loss reduction method is the use of lubricating oils with reduced viscosity $[3,7]$. This solution has a certain limitation. The use of oils with a very low viscosity may lead to deterioration of the lubricating properties which may lead to excessively rapid wear on the working elements or even contribute in seizing up of the motor [4].

The study of internal combustion engines, especially traction motors installed on the engine test bench has an important role in the understanding of the phenomena that occur in the engine, such as e.g. friction losses in the group pistoncylinder. Friction losses in a piston-cylinder largely depend on the thermal state of the engine. Mounting the engine on an engine test bench significantly changes the operating conditions. This results in structural changes for example in the engine cooling system. It should be noted that all changes are adaptive and should not change the course of events to those that occur in the driving vehicle engine [5]. A particularly important role played by the cooling system for the engine mounted on a dynamometer. The laboratory cooling system requires not only the ability to drain the excess heat under all operating conditions, but also the possibility of obtaining precise temperature stabilization.

Engine block coolant temperature determines the temperature of the cylinder and wall oil film covering the cylinder wall. It has a significant impact on the processes of friction occuring in the main engine friction nodes [5, 7]. Besides the node-piston rings and cylinder to total engine friction losses compared to the main part of the bearing and make the crank shaft of the engine. The basis for determining the temperature of the crankshaft bearing is not only the coolant temperature but also the temperature of the oil, usually measured in the oil sump [5].

The article presents the methodology and the results of model and bench testing friction losses in the engine combustion conditions of engine dynanometer variants for different temperatures of lubricating oil and engine speeds.

\section{Model tests methodology of the friction losses in the combustion engine}

The test bench of the model (Fig. 1) was built with a complete engine block FIAT 170A.046 with the crankshaft, connecting rods, pistons and engine head, in order to reproduce as closely as possible the actual working conditions of piston-engine crankshaft in the engine, while ensuring accurate measurement of torque under external drive.

Model test bench was built to measure friction loss in the piston-cylinder group composed of the modified internal combustion engine driven by electric motor from outside. The drive is transmitted through the measuring shaft which allows accurate torque measurement with high temporal resolution. In the engine camshaft is immobilized, leaving all valves in the closed position, there is also the immobilized crankshaft-driven coolant pump and an oil pump replacing them by outer system, driven by electric motors.

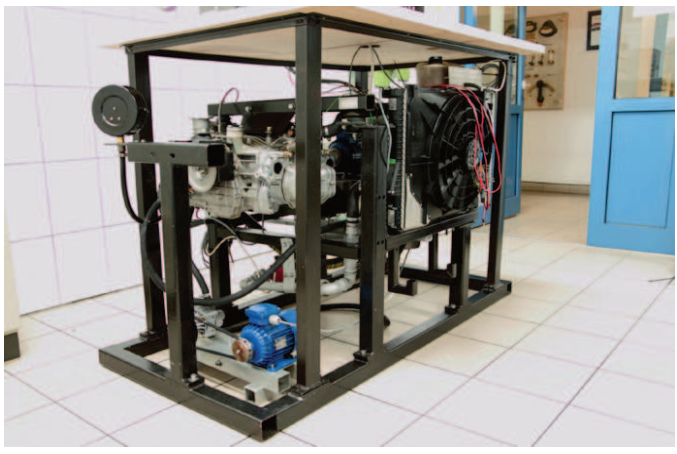

Fig. 1. View of the test bench

The changes made during each revolution of the crankshaft forces the repeating cycle of compression and expan- 
sion of the fuel load confined within the cylinder, where in a portion of the fuel enters the crankcase due to leakage. With the valves closed engine loss charge in the cylinder can be supplemented by additional non-return valves mounted instead of spark plugs and called charge supplement valves. The design position allows you to close the valves or their opening to allow free air intake, ambient or bringing it under certain hypertension. Bringing the cylinder at the beginning of the stroke compressed air under increased pressure causes the increase in the maximum cylinder pressure. This is the method to simulate the actual increased engine load.

A very important element of the original system is to maintain a constant oil temperature of the heat exchanger oilcooling liquid engine, the radiator and heater fluid and electrically powered pumps, coolant and oil. The PID controller makes it possible to maintain the desired oil temperature within $\pm 0.2^{\circ} \mathrm{C}$, which ensures repeatability of the measurements. Diagram of stabilizing the oil temperature at the position shown in Figure 2, and the most important technical data positions in Table 1. A detailed description of the position of the model can be found in the literature [6].

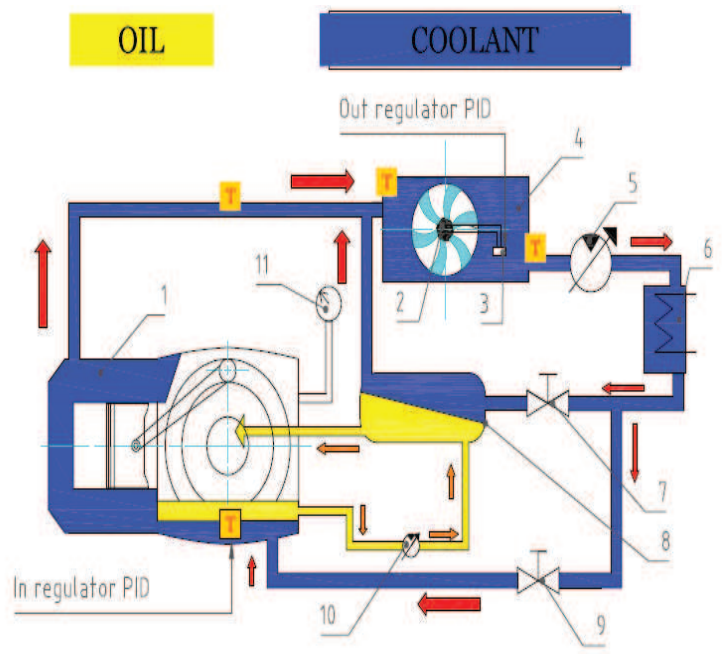

Fig. 2. Diagram of the oil temperature regulation system used on test bench

Table 1. Technical data

\begin{tabular}{|c|l|}
\hline No. & Name \\
\hline 1 & Engine Fiat 170A.046 \\
\hline 2 & Fan radiator fluid \\
\hline 3 & Microprocessor control fan speed \\
\hline 4 & Cooler \\
\hline 5 & Liquid pump with a variable flow rate \\
\hline 6 & Electric heating liquids \\
\hline 7 & The ball valve of a small flow of liquid \\
\hline 8 & The plate heat exchanger of a water / oil \\
\hline 9 & The ball valve of a large flow of the liquid \\
\hline 10 & Oil pump with variable flow \\
\hline 11 & Manometer-pressure oil lubrication system \\
\hline
\end{tabular}

\section{The results of friction losses model studies in the internal combustion engine}

The approach adopted to the construction can capture the position of the torque with high accuracy and measurement frequency (Fig. 3), the measured torque is due to frictional losses in the piston-crank mechanism and is not significantly affected by the action of any other mechanism of the engine. Torque measurement is affected by the influence of thermodynamic phenomena that occur in the engine and charge blow-by to the crankcase.

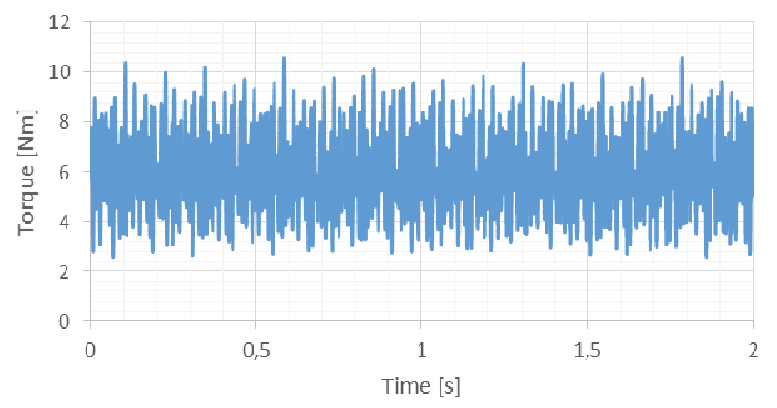

Fig. 3. Registered torque measurement at the speed of $2500 \mathrm{rpm}$ and the oil temperature of $80^{\circ} \mathrm{C}$

The impact of these phenomena cannot be eliminated, but it can be assumed that their progress depends largely on micro-geometry for example or covering coats bearing surface of the piston and that allows mutual comparison of these variants in the range of manufactured friction losses. Model tests were carried out for the factory piston from Fiat engine 170A.046.

The measurements were made for the following conditions:

- engine speed 750-3000 rpm,

- temperature of the oil 50,80 and $110^{\circ} \mathrm{C}$.

As expected, resulting from the hydrodynamic lubrication theory of increasing the rotational speed increases the braking torque. A series of measurements were performed at intervals of several days, then they were averaged and summarized in Fig. 4-7.

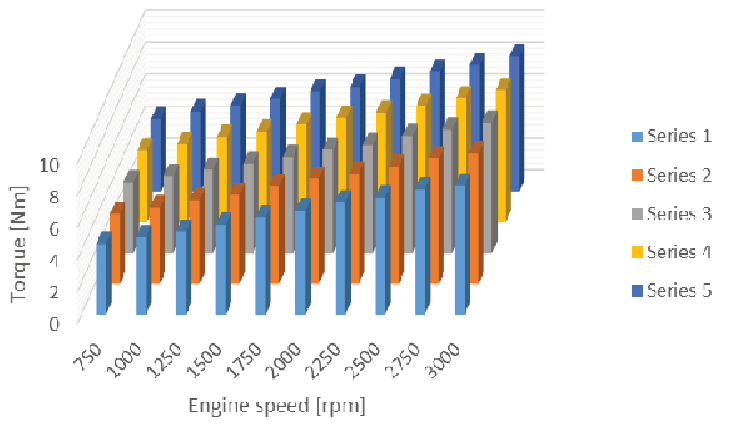

Fig. 4. Course of torque for the five series measuring - oil temperature $50^{\circ} \mathrm{C}$

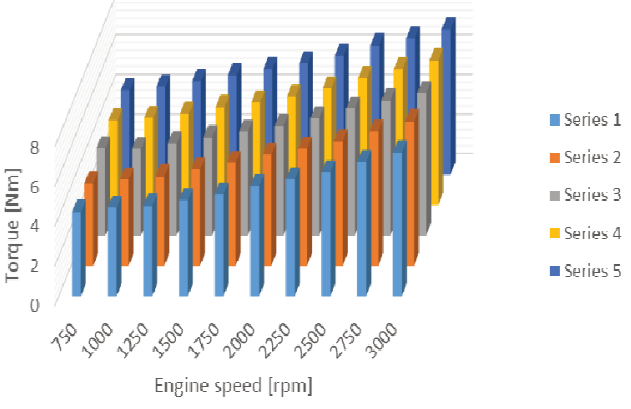

Fig. 5. Course of torque for the five series measuring - oil temperature $80^{\circ} \mathrm{C}$ 


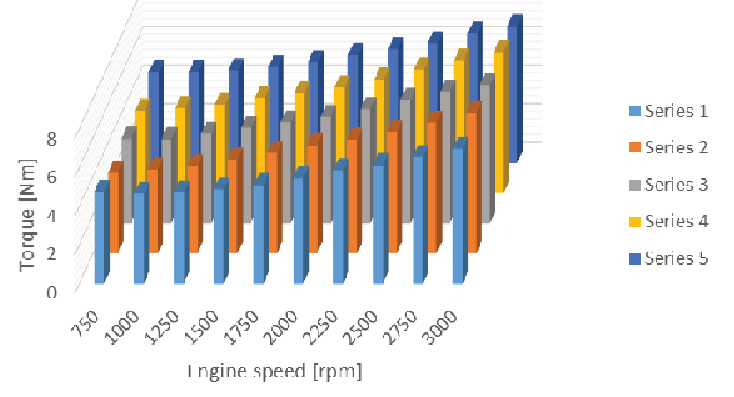

Fig. 6. Course of torque for the five series measuring - oil temperature $110^{\circ} \mathrm{C}$

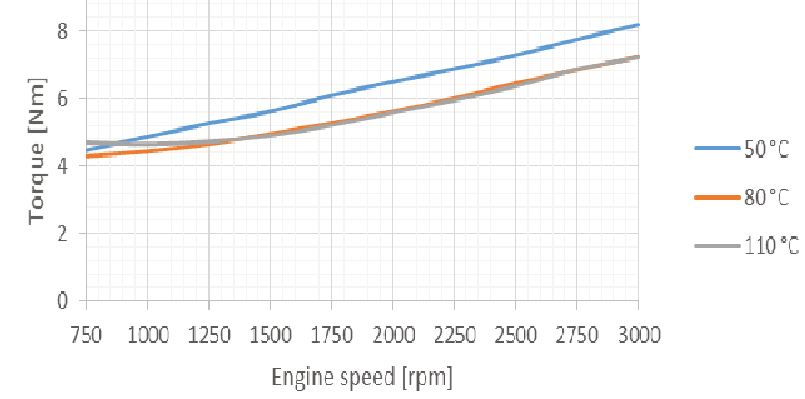

Fig. 7. The plot of averaged torque results for the five series of measurements as a function of oil temperature

On the basis of the results it can be seen that the magnitude of friction loss is higher for higher speeds of the engine.

Temperature 50 and $80^{\circ} \mathrm{C}$ observed increase in braking torque is a monotone throughout the rotation speed range. At these conditions, at an oil temperature of $110^{\circ} \mathrm{C}$ observation leads to the occurrence of a minimum braking torque. For the highest oil temperature speed increase will increase the total friction losses. This is a very important observation because when the engine speed increasing, due to the larger friction losses being converted to heat followed by rapid heating of engine components and lubricating oil, and this contributes to a reduction in viscosity, which may lead to the occurrence of boundary friction conditions.

\section{Methods of friction losses bench tests in the internal combustion engine}

The engine mounted on a test bench (Fig. 8) is manufactured by Volkswagen. Its basic parameters are shown in Table 2.

Table 2. The engine data installed on the test bench [8]

\begin{tabular}{|l|c|}
\hline Built & five-cylinder, in-line \\
\hline Displacement & $2460 \mathrm{~cm}^{3}$ \\
\hline Bore & $81 \mathrm{~mm}$ \\
\hline Stroke & $95.5 \mathrm{~mm}$ \\
\hline Compression ratio & $18.0: 1$ \\
\hline $\begin{array}{l}\text { The number of valves per } \\
\text { cylinder }\end{array}$ & 2 \\
\hline Max power & $96 \mathrm{~kW}$ at $3500 \mathrm{rpm}$ \\
\hline Max torque & $340 \mathrm{Nm}$ at $2000 \mathrm{rpm}$ \\
\hline Built & five-cylinder, in-line \\
\hline Displacement & $2460 \mathrm{~cm}$ \\
\hline Bore & $81 \mathrm{~mm}$ \\
\hline Stroke & $95.5 \mathrm{~mm}$ \\
\hline Exhaust aftertreatment & $\begin{array}{c}\text { exhaust gas recirculation valve, } \\
\text { catalyst }\end{array}$ \\
\hline
\end{tabular}

Research made on the engine are carried out, among others, to assess the impact of the thermal state of the engine lubricating oil on the friction losses.

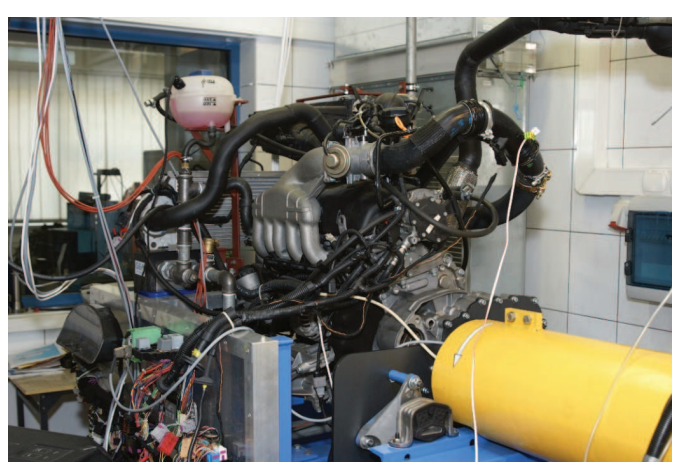

Fig. 8. General view of the test bench

In studies conducted on the analyzed test bench engine, a key role is played by the system regulating the temperature of the engine coolant. This system differs significantly from the original cooling system, which is shown in Figure 9, which is used in vehicles, where it was installed abovementioned engine.

Research carried out in a motor are carried out, among others, to assess the impact of the thermal state of the engine friction losses. Therefore, the position is equipped with a cooling system that gives the possibility of making coolant temperature variants. It is presented in Figure 10.

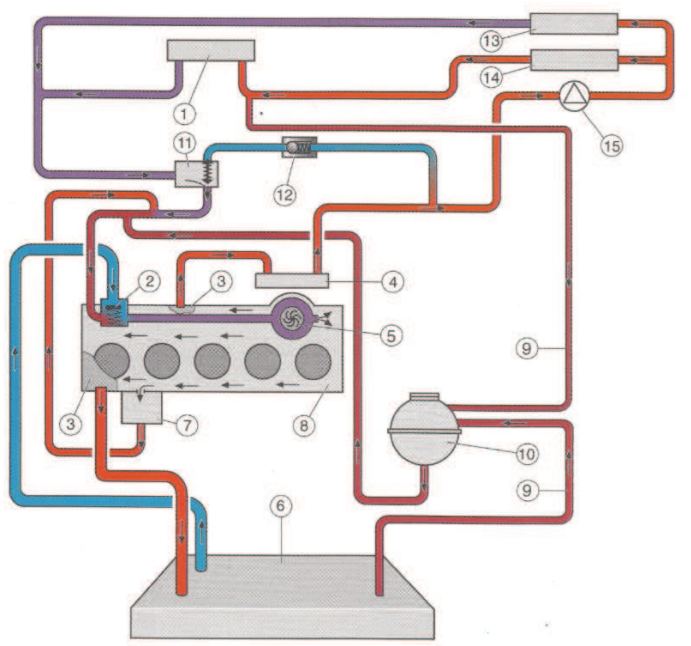

Fig. 9. The standard engine cooling system 2.5 TDI in the car utilitarian VW Transporter T5 [8]: 1 - first heat exchanger, 2 - coolant thermostat, 3 - cylinder head, 4 - exhaust gas recirculation cooler, 5 - coolant pump, 6 - cooler, 7 - oil cooler, 8 - cylinder block, 9 - vent pipe, 10 - expansion tank, 11 - heater coolant shut-off valve N279, 12 - non-return valve, 13 second heat exchanger, 14 - supplementary coolant heater, 15 - recirculation pump

Engine cooling liquid, as in the case of installation in a vehicle, is located in a closed circuit. To its warm up two heaters with power of $10 \mathrm{~kW}$ are used. The controller that has been used is PID type. This controller is designed to establish and maintain a constant temperature of the cooling liquid in variable operating conditions of the engine. Liquid refrigerant for cooling water is supplied from the water mains. The water flows through the heat exchanger and thereby reduces the 
temperature of the coolant. In the control panel, the engine can set the desired temperature of the liquid, which established after some time. Liquid temperature after stabilization of the thermal state should be approximately equal to the temperature of the oil. In the system before the conversion, the value of the coolant temperature can be adjusted significantly in a short period of time, but the time to stabilize the thermal state of the engine was relatively long.

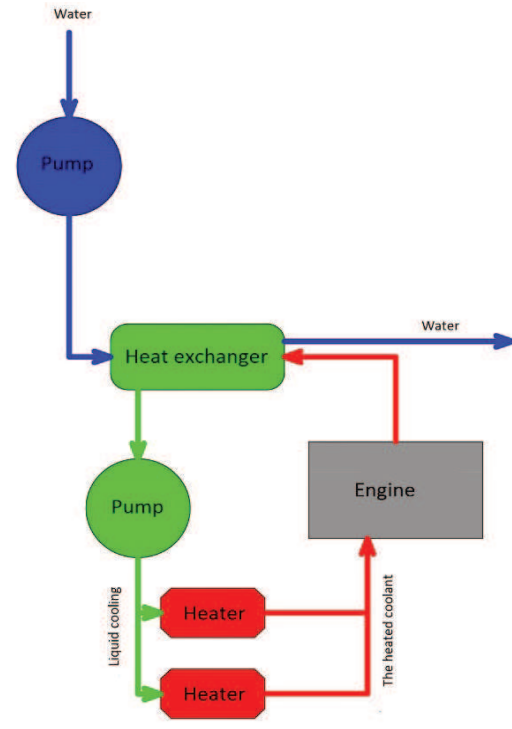

Fig. 10. Diagram of the primary control system of coolant temperature engine on a test bench

The lubrication system does not differ in the construction of the standard system used in the motor mounted in vehicles. The only differences are the temperature sensor in the oil sump and the manometer measures the pressure of the oil injected into the system behind the oil pump.

To the oil supply system are used the warp anchor holes shown in Figure 11, through which flows the oil to various bearings engine, and a transmission gear.

Return oil sump of the engine head is held primarily by the gear shown in Figure 12, and return channels in Figure 13.

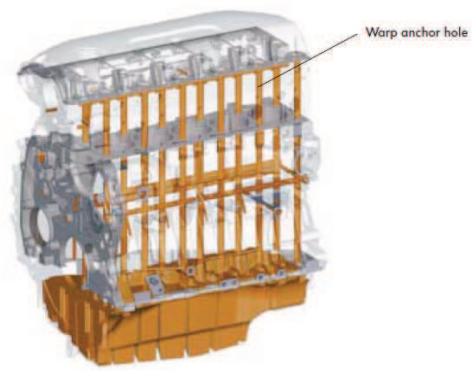

Fig. 11. Oil system power [8]

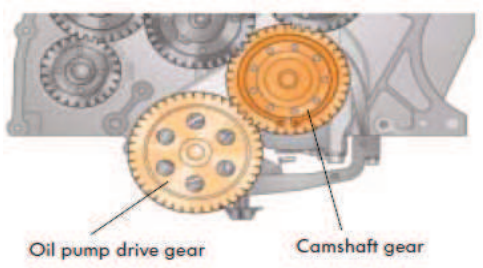

Fig. 12. Oil pump drive [8]

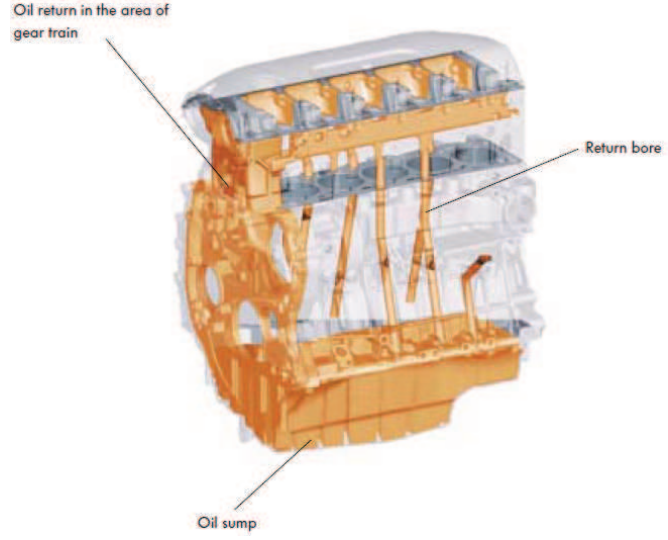

Fig. 13. Lubrication oil return [8]

\section{The tests results of engine friction losses}

Examining resistance of the internal combustion engine, in addition to frictional losses in the bearings of the crankshaft and a group of the piston rings and cylinder-piston unit were measured, also the friction loss due to charge exchange in the cylinder and air compression by the piston drive system in the oil pump.

The measurements were made for the following conditions:

- engine speed 800-2800 rpm,

- oil temperature $55-95^{\circ} \mathrm{C}$.

The results torque and oil pressure were averaged and summarized in the graphs below.

Figure 14 presents a summary of the losses resistance engine resulting from the study for various temperatures of lubricating oil, which are dependent on engine speed. On the loss of resistance engine consists of friction losses in the group piston - rings - cylinder and crankset. In addition, exchange losses in the combustion chamber. Then there are also losses of the drive mechanism of the timing, oil pump and the inertia force of the piston.

The results obtained clearly map the course of the loss resistance of the motor during testing. It follows that the thermal state of the engine lubricating oil has a significant effect on friction loss.

From the graph in Figure 15 it can be concluded that the higher the oil temperature, the smaller is the mechanical resistance in a combustion engine. The reason for this is the lower viscosity of the lubricating oil. It is important to prevent excessive oil temperature, since too low viscosity can result in the direct cooperation of the moving parts up friction, and thus the mixed friction.

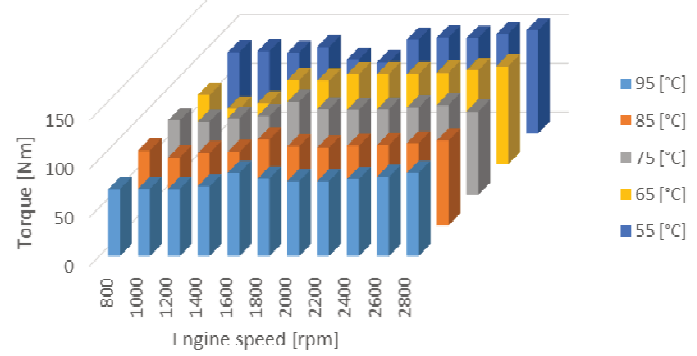

Fig. 14. The results of the motion resistance as a function of engine oil temperature 


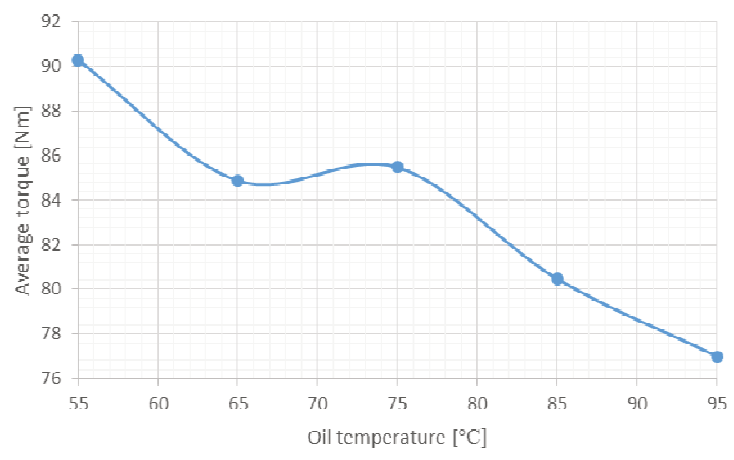

Fig. 15. Averaged torque curve as a function of oil temperature

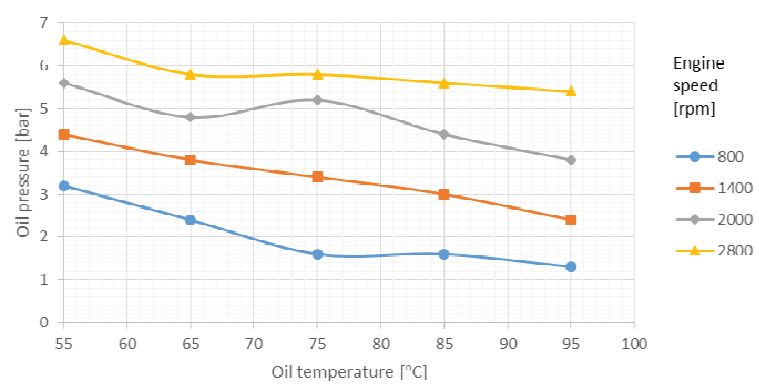

Fig. 16. The oil pressure as a function of oil temperature for different speeds

Also, the resistance losses of the engine depends the phenomenon of charge exchange. With the increase of the rotational speed increase the resistance losses of the motor.

Analyzing the diagram in Figure 16, it can be concluded that the temperature of the oil affects the oil pressure in the lubrication system. At a lower temperature of the lubricating medium pressure increases. The reason for this phenomenon is the viscosity of the oil. At lower temperatures, when the oil has a higher viscosity of the oil pressure must be increased in order to ensure the effectiveness of lubrication in friction. At higher temperatures the viscosity of oil decreases and the pressure which is necessary to deliver oil to the friction in the required amount is smaller.

\section{Conclusions}

The performed research lead to formulating the following conclusions:

- oil temperature measured in the oil sump is reliable in the description of the processes of friction,

- oil temperature has a big influence on the friction loss and other motion resistance in engine. This significantly improves the viscosity of lubricating oil, which decreases under the influence of temperature rise. The higher the viscosity of the oil is, the higher the friction loss in an internal combustion engine,

- oil viscosity is important for the operation of the oil pump. In case of a decrease in viscosity pump generates a higher pressure due to the lower resistance of the oil,

- engine coolant temperature and oil temperature regulate the engine that affects the friction losses,

- increasing speed is followed by rapid heating of the engine and oil. This is due to a higher relative velocity of the moving parts of the engine and as a result of the diffusion of higher temperature,

- increasing the speed at a relatively constant temperature of the oil increases the loss of mechanical resistance,

- for examineted relatively narrow temperature range of oil big changes in the total friction losses were observed. Purposeful independent control of the coolant temperature and oil temperature could significantly contribute to improving the mechanical efficiency of the internal combustion engine under very low loads and speeds.

\section{Bibliography}

[1] DEUSS, T., EHNIS, H., ROSE, R., KÜNZEL, R. Reibleistungsmessungen am Befeuerten Dieselmotor-Einfluss von Kolbenschaftbeschichtungen, MTZ. 2011, 4.

[2] GOLLOCH, R. Untersuchungen zur Tribologie eines Dieselmotors im Bereich Kolbenring/Zylinderlaufbuchse, VDI Verlag GmbH, 2001, 12, 473.

[3] ISKRA, A., KAŁUŻNY, J., BABIAK, M. Charakterystyka biegu jałowego w fazie nagrzewania silnika. Wydawnictwo Politechniki Krakowskiej, 2008.

[4] ISKRA, A., KAŁUŻNY, J., BABIAK, M. Wpływ temperatury cieczy chłodzącej i oleju na straty tarcia w tłokowym silniku spalinowym, Czasopismo Techniczne. 2012, 3-M, 8, 109.

Emil Wróblewski, MEng. - Faculty of Machines and Transport at Poznan University of Technology.

e-mail: emil.z.wroblewski@doctorate.put.poznan.pl

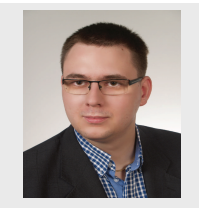

[5] ISKRA, A., WRÓBLEWSKI, E., BABIAK, M. Układ stabilizacji i regulacji stanu cieplnego silnika spalinowego w warunkach hamowni silnikowej, Logistyka. 2015, 3, 1858-1864.

[6] KAŁUŻNY, J. Wpływ kształtu powierzchni nośnej tłoka na parametry filmu olejowego pokrywającego gładź cylindra. Praca doktorska, Wydawnictwo Politechniki Poznańskiej, Poznań, 2004.

[7] WRÓBLEWSKI, E., ISKRA, A., BABIAK, M. The influence of the thermal state of lubricating oil for friction in combustion engine. Journal of Mechanical and Transport Engineering. 2016, 68(2).

[8] Zeszyt do samodzielnego kształcenia nr 305, Silnik 2,5 1 R5 TDI.

Szymon Finke, MEng. - Faculty of Machines and Transport at Poznan University of Technology.

e-mail: szymon.a.finke@doctorate.put.poznan.pl

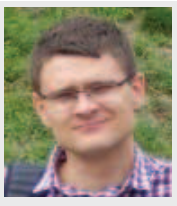

